\title{
Koroid Neovasküler Membranlı Bir Hastada Maküla Deliğinin Spontan Kapanması
}

\author{
Spontaneous Closure of Macular Hole in A Patient with Choroidal Neovascular Membrane \\ Selma URFALIOGLU, Mete GULER, Ismail EVGIN
}

Kahramanmaras Sutcu Imam University School of Medicine, Department of Ophthalmology, Kahramanmaras, Turkey

\section{Özet}

Tam kalınlıkta maküla deliğinin kendiliğinden kapanması nadir bir olaydır ve genellikle cerrahi gerekir. Yetmişbir yaşında kadın hasta, yaşa bağlı maküla dejenerasyonu (YBMD) tanısı ile takip edilmekteydi. Dört yıl once ani görme düșüșünden șikayet etmiști. Görme keskinlikleri sağ ve sol gözde sırasıyla 0.05 ve 1.0 idi. Optik koherens tomografi muayenesinde sağ gözünde tam kalınlıkta maküla deliği ve kuru tip YBMD saptandı. İzlem sırasında kuru tip YBMD'nin yaş tipe değiştiği ve koroid neovasküler membran(KNVM)'ın geliştiği belirlendi. Makula deliği kendiliğinden kapanmış ve aktif KNVM ve epiretinal membrana rağmen görme keskinliği artmıştı. Koroid neovasküler membran maküler deliğin kapanmasını kolaylaştırabilir ve ameliyattan önce kendiliğinden kapanma için gözlem bu iki kombine patolojiye sahip hastalar için bir seçenek olabilir.

Anahtar Kelimeler:Koroid neovasküler membran, Maküler delik, Optik koherens tomografi

\begin{abstract}
Spontaneous closure of a full thickness macular hole is a rare event and usually surgery is needed. A 71 year-old-woman had been followed with the diagnosis of age related macular degeneration (AMD). Four years ago she had complained with sudden vision drop. Visual acuities were 0.05 and 1.0 in right and in left eyes, respectively. On optical coherence tomography examination full thickness macular hole and dry type AMD were detected in her right eye. During follow up it was determined that dry type AMD had changed to wet form and choroidal neovascular membrane (CNVM) had developed. The macular hole had spontenously closed and visual acuity increased despite active CNVM and epiretinal membrane.Choroidal neovascular membrane may facilitate macular hole closure and observation for spontenous closure before surgery may be an option for patients that have these two combined pathologies.
\end{abstract}

Keywords:Choroidal neovascular membrane, Macular hole, Optical coherence tomography

Yazışma Adresi: Mete GÜLER, Kahramanmaraş Sütçü İmam Üniversitesi Tıp Fakültesi Göz Hastalıkları Anabilim Dalı, Kahramanmaraş Türkiye Telefon: +90 (344)3001000, Mail:meteglr@yahoo.com

ORCID No (Sirasıyla):0000-0002-3709-6988,0000-0002-6232-8445, 0000-0001-9142-2505

Geliş tarihi: 11.06 .2020

Kabul tarihi:26.06.2020

DOI: $10.17517 /$ ksutfd.674972 


\section{INTRODUCTION}

Macular hole $(\mathrm{MH})$ is a generally round-shaped neurosensory defect in the foveal region that includes vertically all layers of the retina.It causes painless central vision loss and metamorphopsia in patients. Spontaneous closure of a full thickness $\mathrm{MH}$ is a rare event and usually surgery is needed (1). Here we present spontaneous closure of macular hole in a patient with choroidal neovascular membrane (CNVM).

\section{CASE PRESENTATION}

A 71year-old-woman had been followed with the diagnosis of age related macular degeneration (AMD). Visual acuities were 0.2 in the right eye and 1.0 in the left eye. She had active CNVM (Figure 1) and intravitreal ranibizumab regimen was applied and CNVM was treated. Her left eye was normal (Figure 2). Four years ago she had complained with sudden vision drop. Visual acuities were 0.05 and 1.0 in right and in left eyes, respectively. On OCT examination full thickness $\mathrm{MH}$ and dry type AMD were detected in her right eye (Figure 3) and surgery was suggested, but the patient denied surgery. During the follow-up MH gradually enlarged to 800 micrometers in diameter, an epiretinal membrane was detected and vision dropped to counting fingers (CF) from 1 meter distance (Figure 4). Ten months ago it was determined that dry type AMD had changed to wet form again and CNVM had developed. The MH had spontenously closed and visual acuity increased to CF from 2 meters despite active CNVM and epiretinal membrane (Figure 5). Intravitreal ranibizumab treatment was started again for CNVM.
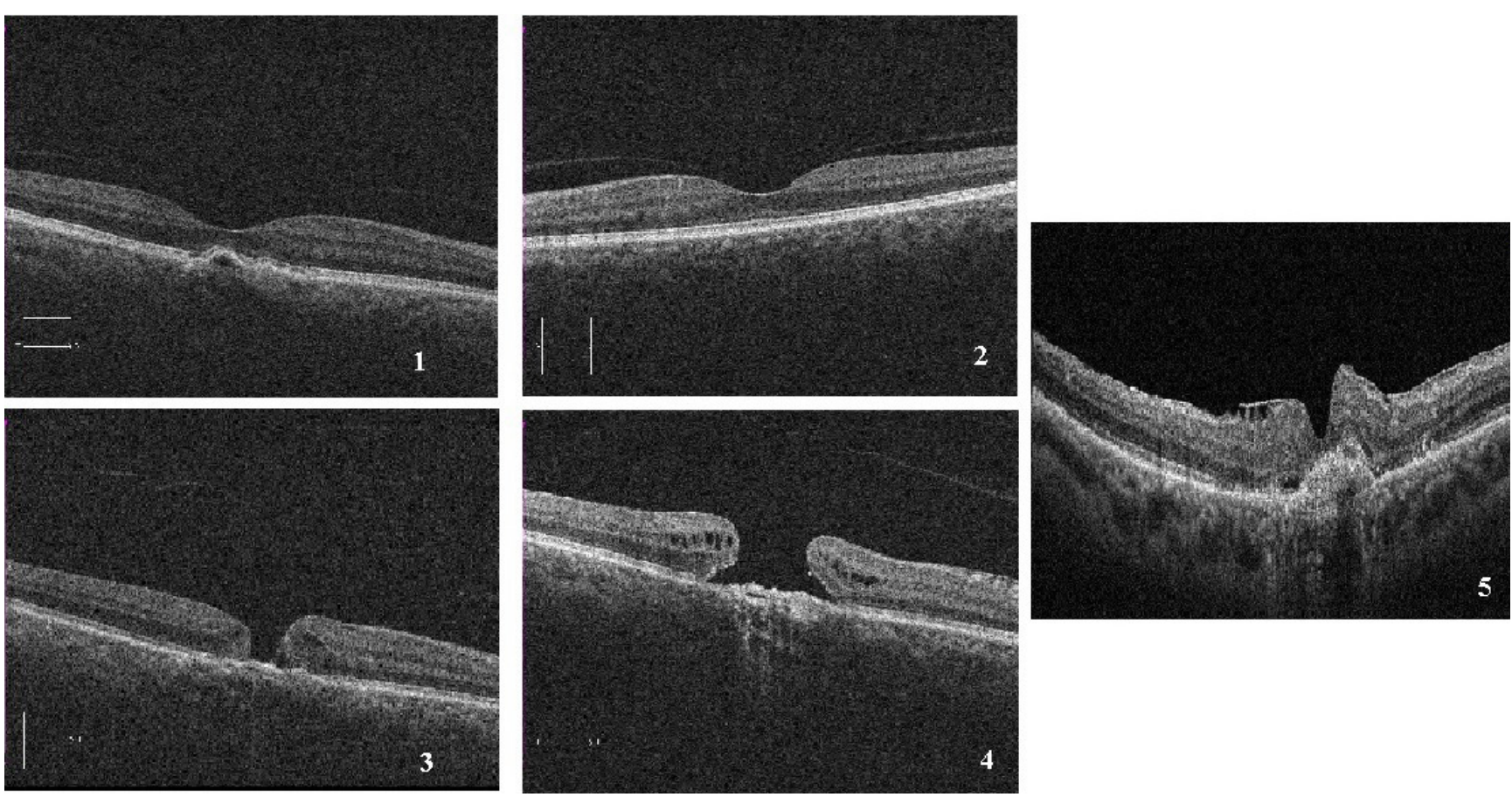

Figure 1. Spectral domain optical coherence tomography image demonstrates a small choroidal neovascular membrane and minimal pigment epithelial detachment.

Figure 2. Normal findings in the left eye in spectral domain optical coherence tomography image.

Figure 3. A small choroidal neovascular membrane and full thickness macular hole is seen in spectral domain optical coherence tomography image.

Figure 4. A large macular hole and choroidal neovascular membrane is seen in spectral domain optical coherence tomography image.

Figure 5. Spectral domain optical coherence tomography image of the right eye shows enlarged and active choroidal neovascular membrane, epiretinal membrane and spontenous closure of $\mathrm{MH}$. 


\section{DISCUSSION}

Several reports have been reported about spontenous closure of macular hole (2-4). On the other hand reports about spontaneous closure of a full-thickness macular hole in patients with CNVM are very rare $(5,6)$. Antero-posterior traction forces that created by vitreous and tangential tractions on the surface of the retina are the most extensively accepted mechanisms regarding the pathogenesis of $\mathrm{MH}$ (6). The aims of vitrectomy surgery in $\mathrm{MH}$ are to remove these abnormal traction forces at the vitreo-macular interface and to promote glial proliferation. In our case, spontaneous closure of the $\mathrm{MH}$ may be caused by two possible mechanisms. CNVM may have caused buckle effect under the fovea with its mass, thus facilitated the bridging the edges of the $\mathrm{MH}$ closer to each other and promoted healing. Adjunctive agents such as growth factors, autologous platelets introduced into the environment by serum leaking from active CNVM may also have stimulated adjacent glial proliferation and facilitated closure (5).In a study Figuero and coworkers used autologous platelet-rich plasma as adjuvant to pars plana vitrectomy with internal limiting membrane peeling in the treatment of highly myopic macular holes and obtained complete closure in all patients (7). These two mechanisms might have also worked in combination.
In conclusion, choroidal neovascular membrane may facilitate MH closure and observation for spontenous closure before surgery may be an option for patients that have these two combined pathologies.

Conflicts of Interest and Financal Status: Our study has not been financed by an institution and institution. In this study there is no conflict of interest among the authors on any subject.

Research Contribution Rate Statement Summary: The authors declare that, they have contributed equally to the manuscript.

\section{REFERENCES}

1. Bikbova G, Oshitari T, Baba T, Yamamoto S, Mori K. Pathogenesis and Management of Macular Hole: Review of Current Advances. J Ophthalmol. 2019;2019:3467381.

2. Bhojwani D, Vasavada S, Sudhalkar A, Vasavada V, Vasavada AR. Acute full-thickness macular hole after uneventful femtosecond-assisted cataract surgery and its spontaneous closure. Indian J Ophthalmol. 2018;66(6):848-849.

3. Nalcı H, Batığlu F, Demirel S, Özmert E. Spontaneous closure of macular hole in a patient with macular telangiectasia type 2 . Retin Cases Brief Rep. 2018 Aug 9.

4. Cohen MN, Baumal CR. Macular hole formation followed by spontaneous closure after pneumatic retinopexy in a patient with diabetic macular edema. Retin Cases Brief Rep. 2021Jan $1 ; 15(1): 24-26$.

5. Su D, Klufas MA, Hubschman JP. Spontaneous Closure of a Full-Thickness Macular Hole With Conversion to Exudative Age-Related Macular Degeneration. JAMA Ophthalmol. 2016 May 1;134(5):604-606.

6. Lee J, Nguyen VQ, Doss MK, Eller AW. Spontaneous closure of a chronic full thickness macular hole after failed surgery. Am J Ophthalmol Case Rep. 2018 Dec 5;13:59-61.

7. Figueroa MS, Govetto A, Arriba-Palomero Pd. Short-term results of platelet-rich plasma as adjuvant to 23-G vitrectomy in the treatment of high myopic macular holes. Eur J Ophthalmol. 2016 Aug 4;26(5):491-496. 